\title{
Investigating the Application of Emergency Remote Teaching During The COVID-19 Pandemic in Higher Education
}

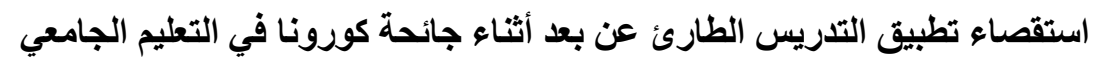

\begin{abstract}
Saudi universities have put immense efforts in preparing and implementing home teaching as an alternative type of traditional teaching during the new coronavirus disease (COVID-19) crisis. The present study aims to focus on outcome of applying Emergency Remote Teaching during the COVID-19 pandemic at Saudi Higher Education. A quantitative research design was used to evaluate the students' perspectives in terms of preparation, implementation, and assessment. A total of 97 students were recruited from Prince Sattam bin Abdul-Aziz University. A self-administered questionnaire, comprising of two parts was provided to the students. The questionnaire's first part collected demographic details of the participants; whereas, second part was distributed into 34 items including preparation (7 items), implementation (8 items), and assessment (7 items), barriers to teaching practices during COVID-19 including 12 items. The results showed that majority of the participant students positively responded towards the application of emergency remote teaching during COVID-19 (3.86 \pm 1.13). Considering the dimensions, preparation $(3.98 \pm 1.12)$, implementation $(3.77 \pm 1.17)$, and assessment $(3.19 \pm 1.30)$, majority of the students gave positive response on majority of the items. Moreover, there was no significant difference in the perspectives about applying emergency remote teaching during COVID-19 between both the genders. The study concluded that most of the students favored emergency remote teaching as it facilitated self-learning.
\end{abstract}

Keywords: COVID-19, Emergency Remote Teaching, Pandemic, Saudi Arabia, Higher Education.

الملخص:

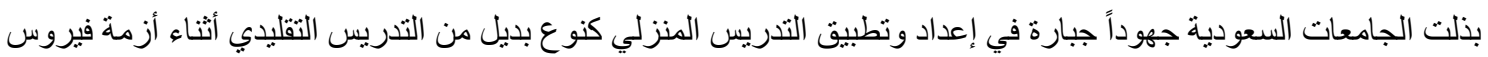

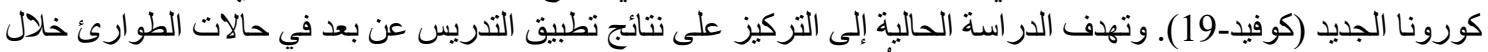

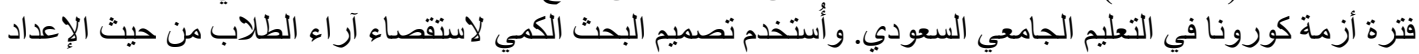

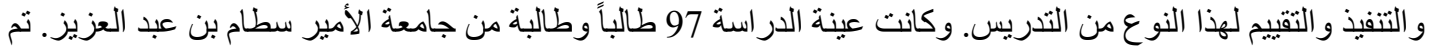
توزيع استبانة ذاتية الإدارة يتكون من فسمين، القسم الأول يتضمن الخصائص الديمو غر افية للمشاركين؛ بينما القسم الثاني

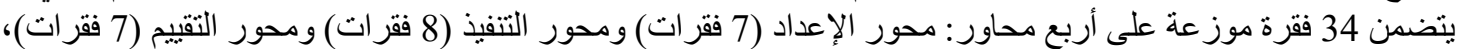

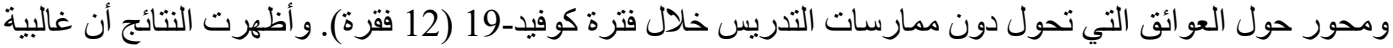

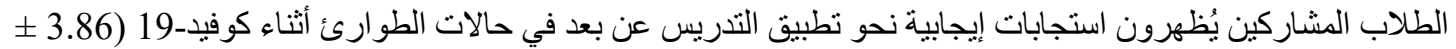

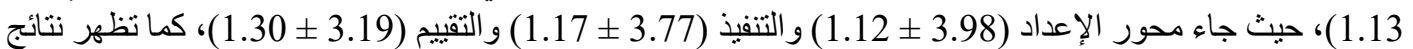

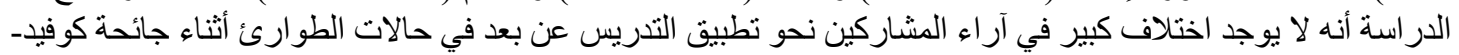

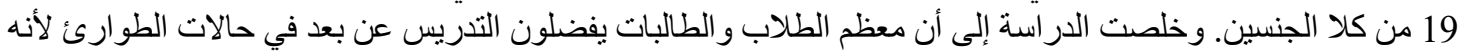
يسهل التعلم الذاتي. الكلمـات المفتاحية: كوفيد-19، التدريس الطارئ عن بعد، جائحة كورونا، السعودية، التعليم العالي

\footnotetext{
${ }^{16}$ Associate Professor, College of Education, Prince Sattam bin Abdulaziz University, Saudi Arabia.
} 


\section{Introduction}

Coronavirus disease (COVID-19) emerged in December 2019 in Wuhan, China, which rapidly spread across the globe. The World Health Organization (WHO) was prompted to declare an official global "pandemic" of COVID-19 in March 2020 due to its swift prevalence (Cho, et al., 2020). Economic conditions become affected, as countries stopped essential businesses such as aviation, markets, and schools, resulting in the decreased attendance at both workplaces and schools with the onset of the COVID-19. Reimers and Schlecher (2020) suggested that leaders of some countries must reduce the impacts of the COVID-19 pandemic, and social distancing must be endured for slowing the spread of infection. Some countries have banned large gatherings, advised individuals not to meet with others outside the family, restricted travel inside and outside the cities, followed by a prolonged shut down universities and schools, due to the spread of the COVID-19 (World Bank, 20201). This left 1.6 billion children and young people out of school or university (World Bank, 2020a). Some countries have resorted to the options like distance learning to mitigate the loss of learning. The educational institutions are unpredictably challenged by COVID-19 pandemic. The leaders of educational institution need to design rapid and appropriate responses to counter this challenge (Reimers et al., 2020). Sladdin (2020) explained that higher education institutions are left with no choice, except an initiation of online communication through Zoom, Moodle, and Skype as the only way to control the virus spread is to practice social distancing. Similarly, Hodges et al. (2020) emphasized that shifting to emergency remote teaching may not be a priority; however, it is convenient as students may not be able to attend courses directly. According to the World Bank (2020a), all educational institutions must develop multi-modal responses as digital technologies can provide a wide range of learning sources. However, some countries, especially low-income countries, may face the obstacles as they lack access to digital devices and highspeed broadband required for online learning. Therefore, the lower-income countries need to adopt other alternative ways for continuation of education outside the schools or universities during COVID-19 crisis.

The Ministry of Education in Saudi Arabia, likewise to its counterparts in other countries, announced the suspension of students' attendance to schools, including university students on 15th March, 2020. The Ministry encouraged universities to continue online teaching, where mostly the system of e-learning through Black Board is used. Universities have tried to prepare students and faculty members in colleges for a shift from teaching face to face to distant learning and teaching. The Saudi Ministry of Education supports implementation of distance teaching in universities to overcome the obstacles (academic or technical), while implementing the remote teaching experience (online). This is due to the emergency posed by the spread of COVD-19, which neither Saudi Arabia nor other countries of the world has expected in general. The universities assisted the faculty to control the quality of the teaching process, which include monitoring the evaluation of students' performance and academic achievement during this crisis. Moreover, the faculty used variety of methods in teaching and evaluation that led the university to change pedagogy and evaluation methods from conventional to e-learning method.

In this instance, Saudi universities have held various meetings and made great efforts to assist in preparing the students and implementing home teaching. Additionally, Prince Sattam bin Abdul-Aziz University (PSAU), one of the Saudi universities located in Al-Kharj Governorate - $80 \mathrm{~km}$ south of the capital Riyadh, applied emergency teaching remotely and worked hard for the quality control of its implementation and evaluation. Notably, PSAU made early preparation for emergency remote teaching and directed its faculty to review its plans to teach online, when the closure of universities was officially announced in Saudi Arabia. The university's administrators clarified the faculty members regarding the process through which students may opt the courses. Furthermore, they devised guidelines for faculty members and students along with providing technical support to faculty members and students.

The elements of the implementation of higher education, performance evaluation, achievements, and obstacles encountered by the students are called into question by the researchers, decision-makers, and those interested in higher education. The evaluation of emergency remote teaching needs to focus on context, inputs and processes, rather than the achievements or outcomes of learning (Hodges et al., 2020). In the similar context, the present study aims to investigate the application of Emergency Remote Teaching during the COVID-19 crisis at Saudi Higher Education. The present study aims to fill the practical gap regarding the successful implementation of emergency remote teaching in higher education for fulfilling the needs of students. It would be possible to improve the in-going practice by knowing how university students learned in the emergency COVID-19. It is also important to highlight the student 
perspectives for improving the learning process in the future, in case if such a situation occurs again. Educational institutions and students alike need to be prepared for any such eventuality in the future. Considering the study aim, following research questions have been constructed:

1. What is the situation of applying emergency remote teaching during the COVID-19 pandemic from postgraduate student' perspectives at Prince Sattam bin Abdulaziz University, in terms of: preparation, implementation and assessment?

2. What are the barriers in applying emergency remote teaching during the COVID-19 pandemic from postgraduate student' perspectives at Prince Sattam bin Abdul-Aziz University?

3. Is there a statistically significant difference between their perspectives in relation to the four dimensions (preparation, implementation, assessment, and barriers) in accordance with their gender, and specialization?

\section{Literature Review}

The normal functioning of schools and universities is disrupted due to actions taken by governments against the COVID-19 pandemic. So, educational institution leaders have sought to develop an alternative to ensure continuing students' learning when going to schools and universities is not possible. Therefore, it was necessary for educational institutions to take immediate decisions to prepare and implement appropriate strategies for the continuation of teaching and learning due to COVID-19.

According to Hodges et al. (2020), the preparation of an e-learning course usually comprises of six to nine months. Besides, the performance of the individuals would not be in a good position, unless they have a good experience, which is not possible in emergency remote teaching. In other words, the aim of emergency remote teaching is to find a temporary solution for teaching that can be employed swiftly the emergency and crisis. Reimers and Schlecher (2020) revealed that the main concern of researchers and experts is that the extensive dropout from schools may lead to loss of acquired knowledge and skills. Therefore, countries may differ in providing appropriate educational opportunities for their people during the crisis. In other words, learning opportunities between countries may be different due to the difference in students' motivation for distance learning, parents' support in providing resources required for remote learning, the ability of schools and universities to support their students remotely, or difference in the ability of education management to design appropriate effective responses.

The establishment of effective learning during COVID-19 will be dependent on educational institutions in providing alternative and suitable learning methods, although most students have access to digital devices in the present age. Reimers, et al. (2020) categorized educational sources to three sections; curriculum sources, tools, and professional development resources that can be provided by educational institutes during the COVID-19 time.

According to the World Bank (World Bank, 2020b), there is difference in distance learning strategies for different levels of education. For example, the younger students need more audio/visual stimulation; whereas, older students possess greater tendency for independent learning. This emphasizes that the online learning mode may specifically have a higher propensity for undergraduate students. Typically, this is facilitated by concurrent video conferencing system and Learning Management Systems (LMS).

Therefore, the World Bank (World Bank, 2020a) recommended some general principles for policy makers in different countries to design and implement distance learning strategies during a crisis such as COVID-19:

- Firstly, educational policy makers should plan and prepare for a multi-faceted remote learning model. For example, they should develop short and long-term plans of remote learning with cooperation and consultation with external stakeholders (e.g., ministries of information and communications technology). Also, an inventory of existing content is needed to be created by policymakers via remote learning (especially free and open sources), instead of developing new content which may require additional expertise. They should also organize the content that align with existing approaches, and ensure that learning opportunities are compatible with educational goals. In addition, a virtual help desk is needed to support teachers and students.

- Secondly, educational policymakers should implement the offline learning model during the COVID-19 crisis. More specifically, policymakers need to devise various ways through which the student`s learning can continue offline along with technology as a supportive tool. For instance, the 
students can learn at home by taking advantage of printed materials like textbooks, reading lists, projects, and printed study guides. However, the main challenge is how to distribute these materials when they cannot be delivered physically. In this case, if technology like WhatsApp permits than books and other materials can be distributed electronically.

- Thirdly, educational decision makers should provide a variety of techniques of distance teaching during crises (such as COVID-19). For example, educational institutions can apply the radio distance learning model, such as making use of educational radio or educational television. They can also apply the mobile-distance learning model, especially with the limited availability of other technologies and with the spread of mobile phones. The videos are also a valuable learning resource, in case of having attractive content. The enthusiasm and engagement among the students can be enhanced simply by recording a long lecture and making it available online (like YouTube).

In general, programs to prepare teachers to deal with varied demands of COVID-19 pandemic need to be strengthened through essential insights about information, communication and technology-embedded teaching.

\section{Method}

\section{Study Design and Setting}

The study employed quantitative research design to investigate the current situation of applying emergency remote teaching during the COVID-19 pandemic from postgraduate students' perspectives at Prince Sattam bin Abdul-Aziz University. This quantitative study would tentatively work as a way of conceptualizing and encapsulating the experiences of teachers and students during emergency remote teaching-learning. The perspectives were evaluated in terms of preparation, implementation, and assessment to explore the barriers in applying emergency remote teaching for their perspectives. The analysis of these experiences provided a new level of insight regarding the implementation emergency remote teaching due to the outbreak of COVID-19.

\section{Study Sample}

The sample included all postgraduate students at PSAU, as the number of students were limited. The purpose of recruiting students in this study was to identify their perspectives and experiences regarding remote classes. In this regard, a survey was conducted by engaging students at PSAU. An informed consent form was sent to all the participants by emails that had to be signed before starting the study procedure. A total of 97 responses were obtained, from 49 female and 48 male participants. The complete demographic detail of the participants is provided in Table 1.

Table 1.

Demographic profile of the teacher participants.

\begin{tabular}{|c|c|c|c|}
\hline Variable & Categories & Frequencies & Percentages \\
\hline \multirow{2}{*}{ Geder } & Male & 48 & $49.5 \%$ \\
\hline & Female & 49 & $50.5 \%$ \\
\hline \multirow{7}{*}{ College } & Education & 35 & $36.1 \%$ \\
\hline & Business Administration & 10 & $10.3 \%$ \\
\hline & Humanities and Sciences & 18 & $18.6 \%$ \\
\hline & Applied Medical Sciences & 10 & $10.3 \%$ \\
\hline & Engineering & 11 & $11.3 \%$ \\
\hline & Pharmacy & 12 & $12.4 \%$ \\
\hline & Computer Science Engineering & 1 & $1.0 \%$ \\
\hline \multirow{3}{*}{ Specialty } & Humanitarian & 40 & $41.2 \%$ \\
\hline & Health & 23 & $23.7 \%$ \\
\hline & Scientific & 34 & $35.1 \%$ \\
\hline \multirow{4}{*}{$\begin{array}{l}\text { The devices that you used to } \\
\text { learn remotely during the } \\
\text { COVID-19 pandemic }\end{array}$} & A computer & 11 & $11.3 \%$ \\
\hline & Laptop & 35 & $36.0 \%$ \\
\hline & IPad & 10 & $10.3 \%$ \\
\hline & Smartphone & 41 & $42.2 \%$ \\
\hline
\end{tabular}




\section{Study Procedure}

The study procedure including the completion of self-administered survey at any time and at their own chosen place according to their convenience (Robson, 2002). The first part of the survey collected information related to demographics included; gender, college, and their specialty. Also, they were asked about the devices used to learn remotely during the COVID-19 pandemic. This aspect helped in understanding the background of all the respondents, which further facilitated to test different variables. The questionnaire's second part inquired about researcher's experience on the literature. There were total of 34 items including two parts. The former was to assess the situation of teaching practices during COVID-19 including preparation (7 items), implementation (8 items), and assessment (7 items). While, the latter aimed to examine the pedagogical barriers during COVID-19 including 12 items. In the first part, 5 -point Likert scale that ranged from strongly disagree to strongly agree was used; whereas, in the second part, 4-point Likert scale (not limited, slightly limited, somewhat limited, greatly limited) was used.

\section{Validity Internal Consistency}

The validity of the internal consistency was examined using Pearson correlation coefficient related to applying emergency remote teaching. Pearson correlation coefficient ranged between 0.830 and 0.852 for the correlation among each dimension. The statistically significance value for all these coefficients was set at level <.01 (Table 2).

Table 2.

Pearson Correlation Coefficients Between Each Statement and Each Deminsion Related to Applying Emergency Remote Teaching.

\begin{tabular}{|c|c|c|c|c|c|c|}
\hline & \multicolumn{2}{|l|}{ Preparation } & \multicolumn{2}{|c|}{ Implementation } & \multicolumn{2}{|l|}{ Assessment } \\
\hline Items & $\begin{array}{l}\text { Pearson } \\
\text { correlation } \\
\text { coefficient }\end{array}$ & $\begin{array}{l}\text { P-Value } \\
\text { (Sig) }\end{array}$ & $\begin{array}{l}\text { Pearson } \\
\text { correlation } \\
\text { coefficient }\end{array}$ & $\begin{array}{l}\text { P-Value } \\
\text { (Sig) }\end{array}$ & $\begin{array}{l}\text { Pearson } \\
\text { correlation } \\
\text { coefficient }\end{array}$ & $\begin{array}{l}\text { P-Value } \\
\text { (Sig) }\end{array}$ \\
\hline 1 & $0.484 * *$ & 0.003 & $0.676^{* *}$ & 0.000 & $0.654 * *$ & 0.000 \\
\hline 2 & $0.588 * *$ & 0.000 & $0.518 * *$ & 0.002 & $0.736 * *$ & 0.000 \\
\hline 3 & $0.731 * *$ & 0.000 & $0.744 * *$ & 0.000 & $0.469 * *$ & 0.004 \\
\hline 4 & $0.809 * *$ & 0.000 & $0.730 * *$ & 0.000 & $0.580 * *$ & 0.000 \\
\hline 5 & $0.687 * *$ & 0.000 & $0.736 * *$ & 0.000 & $0.597 * *$ & 0.000 \\
\hline 6 & $0.699 * *$ & 0.000 & $0.825^{* *}$ & 0.000 & $0.705^{* *}$ & 0.000 \\
\hline 7 & $0.516^{* *}$ & 0.002 & $0.792 * *$ & 0.000 & $0.646^{* *}$ & 0.000 \\
\hline 8 & & & $0.645 * *$ & 0.000 & & \\
\hline Overall & $0.830 * *$ & 0.000 & $0.851 * *$ & 0.000 & $0.852 * *$ & 0.000 \\
\hline
\end{tabular}

\section{Statistical Reliability}

The reliability coefficient measuring the reliability of a set of items was examined using Cronbach's Alpha (Cronbach, 1951). In the present study, Cronbach's alpha of the four dimensions was 0.769 for the preparation dimension, 0.857 for implementation dimension, 0.830 for assessment dimension, and 0.722 for barriers dimension. The overall reliability coefficients were 0.862 . The Cronbach's Alpha value of reliability at an acceptable level was either 0.7 or higher (Field, 2017).

Table 3.

Reliability coefficients Cronbach's alpha.

\begin{tabular}{lll}
\hline Dimension & Items & Coefficients Cronbach's alpha \\
\hline Preparation & 7 & 0.769 \\
Implementation & 8 & 0.857 \\
Assessment & 7 & 0.830 \\
Overall reliability in Applying teaching & 22 & 0.902 \\
Obstacles & 12 & 0.722 \\
Overall reliability coefficients in all questionnaire & 34 & 0.862 \\
\hline
\end{tabular}




\section{Data Analysis}

IBM- SPSS Statistics for Windows was used to perform the data analysis (IBM Corp, 2017). The descriptive statistics of each dimension from the participants' perspectives were determined separately. The main reason of analyzing data according to gender and specialization was that that it helped in investigating the challenges and achievement in emergency remote teaching, needs of teachers need, and attitude towards remote teaching-learning.

\section{Results}

The present study includes results that are based on the perspectives of postgraduate students. Mean and standard deviation were conducted for dimensions (preparation, implementation and assessment) to examine the situation of applying emergency remote teaching during the COVID-19 pandemic (Table 4). Most postgraduate students were positive about applying emergency remote teaching during the COVID-19. The overall mean is 3.86 with a standard deviation of 1.13 .

Table 4.

Mean and Standard Deviation for the dimension of perparation, implementation and assessment.

\begin{tabular}{llllll}
\hline No & Dimension & Mean & Standard deviation & Ranking & Interpretation \\
\hline 1 & Preparation & 3.98 & 1.12 & 1 & Agree \\
3 & Assessment & 3.82 & 1.10 & 2 & Agree \\
2 & Implementation & 3.77 & 1.17 & 3 & Agree \\
& Overall mean (all dimensions) & 3.86 & 1.13 & - & Agree \\
\hline
\end{tabular}

\section{Preparation}

The first dimension included seven items that are the determinants of preparation of applying emergency remote teaching at Prince Sattam bin Abdul-Aziz University during the COVID-19 from the participants' perspectives (Table 5). Most of the students agreed that they were prepared to use technical programs and methods of remote teaching during the COVID-19 pandemic. The overall mean was 3.98 with a standard deviation of 1.12. All the items indicating high ratings ranged from $81.4 \%$ to $60.8 \%$ (Table 5).

Table 5.

Perspective of Respondents Regarding The Dimension of Preparation.

\begin{tabular}{|c|c|c|c|c|c|c|}
\hline No & Statement & $\mathbf{N}(\%)$ & Mean & $\begin{array}{l}\text { Standard } \\
\text { deviation }\end{array}$ & Ranking & $\begin{array}{l}\text { Interpre } \\
\text { tation }\end{array}$ \\
\hline 6 & $\begin{array}{l}\text { I communicate with the course lecturer } \\
\text { online easily through email, discussion } \\
\text { forum, instant chats, and others }\end{array}$ & $74(76.3 \%)$ & 4.22 & 1.17 & 1 & $\begin{array}{l}\text { Strongly } \\
\text { agree }\end{array}$ \\
\hline 3 & $\begin{array}{l}\text { During the COVID- } 19 \text { pandemic, I } \\
\text { learned about the use of technical } \\
\text { programs that help with teaching, such } \\
\text { as Zoom, Microsoft Team }\end{array}$ & $74(76.3 \%)$ & 4.11 & 1.10 & 2 & Agree \\
\hline 2 & $\begin{array}{l}\text { I can use e-learning systems such as } \\
\text { blackboard and its tools }\end{array}$ & $79(81.4 \%)$ & 4.08 & 1.01 & 3 & Agree \\
\hline 4 & $\begin{array}{l}\text { The course lecturer explained to me the } \\
\text { methods of remote teaching during the } \\
\text { COVID-19 pandemic }\end{array}$ & $74(76.3 \%)$ & 4.01 & 1.12 & 4 & Agree \\
\hline 5 & $\begin{array}{l}\text { It became clear to me the methods of } \\
\text { assessing the course (assignments, } \\
\text { posts, electronic tests, etc.) during the } \\
\text { COVID- } 19 \text { pandemic }\end{array}$ & $72(74.2 \%)$ & 3.97 & 1.08 & 5 & Agree \\
\hline 7 & $\begin{array}{l}\text { Emergency remote teaching created an } \\
\text { appropriate learning environment } \\
\text { during the COVID-19 pandemic }\end{array}$ & $62(63.9 \%)$ & 3.88 & 1.25 & 6 & Agree \\
\hline 1 & $\begin{array}{l}\text { Educational letters and messages } \\
\text { (guidelines / videos) helped me to } \\
\text { prepare for emergency remote teaching }\end{array}$ & $59(60.8 \%)$ & 3.62 & 1.12 & 7 & Agree \\
\hline \multicolumn{2}{|c|}{ Overall mean } & & 3.98 & 1.12 & - & Agree \\
\hline
\end{tabular}




\section{Implementation}

The second dimension included eight items, which has determined the implementation of applying emergency remote teaching at Prince Sattam bin Abdul-Aziz University during the COVID-19 from the participants' perspectives. The postgraduate students mostly agreed on all the items corresponding to implementation of emergency remote teaching at Prince Sattam bin Abdul-Aziz University during the COVID-19. Such that they agreed that emergency remote teaching facilitated self-learning, expressing opinions easily, encouraging to read course topics, and understanding of the scientific content well. The overall mean was 3.77 with a standard deviation of 1.17 (Table 6). All the items indicating high ratings ranged from $85.6 \%$ to $43.3 \%$.

Table 6.

Perspective of Respondents Regarding The Dimension of Implementation.

\begin{tabular}{|c|c|c|c|c|c|c|}
\hline No & Statement & $\mathbf{N}(\%)$ & Mean & $\begin{array}{l}\text { Standard } \\
\text { deviation }\end{array}$ & Ranking & $\begin{array}{l}\text { Interpre } \\
\text { tation }\end{array}$ \\
\hline 2 & $\begin{array}{l}\text { I have attended the synchronized } \\
\text { lectures on time }\end{array}$ & $83(85.6 \%)$ & 4.45 & 0.91 & 1 & $\begin{array}{l}\text { Strongly } \\
\text { agree }\end{array}$ \\
\hline 6 & $\begin{array}{l}\text { The emergency remote teaching } \\
\text { facilitated self-learning }\end{array}$ & $77(79.4 \%)$ & 4.09 & 1.05 & 2 & Agree \\
\hline 5 & $\begin{array}{l}\text { The emergency remote teaching helped } \\
\text { me to participate and express my } \\
\text { opinion easily }\end{array}$ & $73(75.3 \%)$ & 3.99 & 1.11 & 3 & Agree \\
\hline 7 & $\begin{array}{l}\text { The emergency remote teaching } \\
\text { encouraged me to continue reading on } \\
\text { the course topics }\end{array}$ & $71(73.2 \%)$ & 3.84 & 1.13 & 4 & Agree \\
\hline 8 & $\begin{array}{l}\text { I feel comfortable when emergency } \\
\text { teaching is done remotely at home }\end{array}$ & $63(64.9 \%)$ & 3.78 & 1.37 & 5 & Agree \\
\hline 4 & $\begin{array}{l}\text { The content of scientific materials is } \\
\text { available online }\end{array}$ & $42(43.3 \%)$ & 3.38 & 1.25 & 6 & Neutral \\
\hline 1 & $\begin{array}{l}\text { Emergency remote teaching helped me } \\
\text { understand the scientific content well }\end{array}$ & $47(48.5 \%)$ & 3.37 & 1.21 & 7 & Neutral \\
\hline 3 & $\begin{array}{l}\text { I can listen to the recorded lectures at } \\
\text { any time }\end{array}$ & $42(43.3 \%)$ & 3.27 & 1.31 & 8 & Neutral \\
\hline \multicolumn{3}{|c|}{ Overall mean } & 3.77 & 1.17 & - & Agree \\
\hline
\end{tabular}

\section{Assessment}

Another dimension of applying emergency remote teaching is assessment, which included seven items as shown in table 7. The postgraduate students gave positive response about assessment in emergency remote teaching for most of the items. However, 39.2\% students agreed that evaluation methods cover the theoretical and applied aspects of the course (3.19 \pm 1.30$)$.

Table 7.

Perspective of Respondents Regarding The Dimension of Assessment.

\begin{tabular}{|c|c|c|c|c|c|c|}
\hline No & Statement & $\mathbf{N}(\%)$ & Mean & $\begin{array}{l}\text { Standard } \\
\text { deviation }\end{array}$ & Ranking & $\begin{array}{l}\text { Interpreta } \\
\text { tion }\end{array}$ \\
\hline 6 & $\begin{array}{l}\text { The course lecturer uses research } \\
\text { projects as one of the evaluation } \\
\text { methods }\end{array}$ & $78(80.4 \%)$ & 4.18 & 0.98 & 1 & Agree \\
\hline 5 & $\begin{array}{l}\text { The course lecturer uses a variety of } \\
\text { evaluation methods, such as } \\
\text { homework and presentations, } \\
\text { participation in a discussion forum, } \\
\text { and others, during emergency remote } \\
\text { teaching }\end{array}$ & $74(76.3 \%)$ & 4.16 & 1.04 & 2 & Agree \\
\hline 7 & $\begin{array}{l}\text { Emergency remote teaching helped } \\
\text { me get feedback online (like email, } \\
\text { discussion forums, etc.) }\end{array}$ & $70(72.2 \%)$ & 3.90 & 1.04 & 3 & Agree \\
\hline 1 & $\begin{array}{l}\text { Emergency remote teaching helped } \\
\text { me to perform my homework and } \\
\text { duties easily }\end{array}$ & $67(69.1 \%)$ & 3.86 & 1.17 & 4 & Agree \\
\hline
\end{tabular}




\begin{tabular}{|c|c|c|c|c|c|c|}
\hline 4 & $\begin{array}{l}\text { Became using self-evaluation with } \\
\text { emergency remote teaching }\end{array}$ & $60(61.9 \%)$ & 3.79 & 1.02 & 5 & Agree \\
\hline 2 & $\begin{array}{l}\text { The evaluation methods used in } \\
\text { emergency remote teaching are } \\
\text { appropriate for me }\end{array}$ & $58(59.8 \%)$ & 3.66 & 1.17 & 6 & Agree \\
\hline \multirow[t]{2}{*}{3} & $\begin{array}{l}\text { The evaluation methods cover the } \\
\text { theoretical and applied aspects of the } \\
\text { course }\end{array}$ & $38(39.2 \%)$ & 3.19 & 1.30 & 7 & Neutral \\
\hline & Overall mean & & 3.82 & 1.10 & - & Agree \\
\hline
\end{tabular}

\section{Barriers}

The study has focused on barriers while applying emergency remote teaching during COVID-19 pandemic from postgraduate students' perspectives at Prince Sattam bin Abdul-Aziz University. Table 8 shows the percentages of the participants with conducting comparison between the 'greatly limited and somewhat limited' in one column and 'slightly limited and not limited' in another column. The top three barriers were found as homework and duties have increased with emergency remote teaching, weak internet connection at home, and the nature of their courses was not appropriate for emergency remote teaching. Other barriers included poor suitability of the home environment for learning, imposing synchronized learning electronically as one way to present the scientific content, and the inability of course lecturer to use the e-learning system well.

Table 8.

Descriptive Statistics of The Participant' Perspectives About Barriers in Applying Emergency Remote Teaching During COVID-19.

\begin{tabular}{|c|c|c|c|c|c|c|c|}
\hline No & Statement & $\begin{array}{l}\text { Greatly } \\
\text { limited/So } \\
\text { mewhat } \\
\text { limited }\end{array}$ & $\begin{array}{l}\text { Slightly } \\
\text { limited/Not } \\
\text { limited }\end{array}$ & Mean & $\begin{array}{l}\text { Standard } \\
\text { deviation }\end{array}$ & $\begin{array}{l}\text { Ran } \\
\text { king }\end{array}$ & $\begin{array}{l}\text { Interpre } \\
\text { tation }\end{array}$ \\
\hline 6 & $\begin{array}{l}\text { With emergency remote } \\
\text { teaching, homework and } \\
\text { duties have increased }\end{array}$ & $74(76.3 \%)$ & $23(23.7 \%)$ & 2.10 & 0.99 & 1 & $\begin{array}{l}\text { Somewh } \\
\text { at limited }\end{array}$ \\
\hline 1 & $\begin{array}{l}\text { Weakness internet connection } \\
\text { at home }\end{array}$ & $68(70.1 \%)$ & $29(29.9 \%)$ & 2.01 & 0.99 & 2 & $\begin{array}{l}\text { Somewh } \\
\text { at limited }\end{array}$ \\
\hline 10 & $\begin{array}{l}\text { The nature of my courses was } \\
\text { not appropriate for emergency } \\
\text { remote teaching }\end{array}$ & $41(42.3 \%)$ & $56(57.7 \%)$ & 1.35 & 1.12 & 3 & $\begin{array}{l}\text { Slightly } \\
\text { limited }\end{array}$ \\
\hline 3 & $\begin{array}{l}\text { Difficulty entering the e- } \\
\text { learning system (Blackboard) }\end{array}$ & $42(43.3 \%)$ & $55(56.7 \%)$ & 1.23 & 1.05 & 4 & $\begin{array}{l}\text { Slightly } \\
\text { limited }\end{array}$ \\
\hline 4 & $\begin{array}{l}\text { Difficulty dealing with } \\
\text { programs attached to the e- } \\
\text { learning system (such as } \\
\text { Blackboard-Collaborate, } \\
\text { Zoom, etc.) }\end{array}$ & $40(41.2 \%)$ & $57(58.8 \%)$ & 1.20 & 0.99 & 5 & $\begin{array}{l}\text { Slightly } \\
\text { limited }\end{array}$ \\
\hline 8 & $\begin{array}{l}\text { The lack of fairness in } \\
\text { evaluation when using } \\
\text { electronic evaluation methods }\end{array}$ & $36(37.1 \%)$ & $61(62.9 \%)$ & 1.14 & 1.15 & 6 & $\begin{array}{l}\text { Slightly } \\
\text { limited }\end{array}$ \\
\hline 11 & $\begin{array}{l}\text { The weakness of technical } \\
\text { support at the university when } \\
\text { I need it }\end{array}$ & $34(35.1 \%)$ & $63(64.9 \%)$ & 1.09 & 1.09 & 7 & $\begin{array}{l}\text { Slightly } \\
\text { limited }\end{array}$ \\
\hline 2 & $\begin{array}{l}\text { I do not have suitable devices } \\
\text { to access the e-learning } \\
\text { platforms }\end{array}$ & $32(33.0 \%)$ & $65(67.0 \%)$ & 1.06 & 1.11 & 8 & $\begin{array}{l}\text { Slightly } \\
\text { limited }\end{array}$ \\
\hline 5 & $\begin{array}{l}\text { Emergency remote teaching } \\
\text { does not provide me with } \\
\text { positive interaction in the } \\
\text { learning environment }\end{array}$ & $27(27.8 \%)$ & $70(72.2 \%)$ & 1.04 & 0.95 & 9 & $\begin{array}{l}\text { Slightly } \\
\text { limited }\end{array}$ \\
\hline 12 & $\begin{array}{l}\text { The poor suitability of the } \\
\text { home environment for } \\
\text { learning }\end{array}$ & $34(35.1 \%)$ & $63(64.9 \%)$ & 1.03 & 1.08 & 10 & $\begin{array}{l}\text { Slightly } \\
\text { limited }\end{array}$ \\
\hline 9 & $\begin{array}{l}\text { Imposing synchronized } \\
\text { learning electronically as one }\end{array}$ & $25(25.8 \%)$ & $72(74.2 \%)$ & 0.94 & 0.96 & 11 & $\begin{array}{l}\text { Slightly } \\
\text { limited }\end{array}$ \\
\hline
\end{tabular}




\begin{tabular}{|c|c|c|c|c|c|c|c|}
\hline \multirow[t]{2}{*}{7} & $\begin{array}{l}\text { way to present the scientific } \\
\text { content } \\
\text { The course lecturer was } \\
\text { unable to use the e-learning } \\
\text { system well }\end{array}$ & \multirow[t]{2}{*}{$28(28.9 \%)$} & \multirow[t]{2}{*}{$69(71.1 \%)$} & 0.90 & 0.98 & 12 & $\begin{array}{l}\text { Slightly } \\
\text { limited }\end{array}$ \\
\hline & Overall mean & & & 1.26 & 1.04 & - & $\begin{array}{l}\text { Slightly } \\
\text { limited }\end{array}$ \\
\hline
\end{tabular}

\section{Gender differences}

The differences in perspective between male and female participants regarding application of emergency remote teaching during the COVID-19 was examined through mean scores, standard deviations, and independent samples t-test (Table 9). The results revealed no statistically significant differences in the perspectives about applying emergency remote teaching at Prince Sattam bin Abdul-Aziz University during the COVID-19 between the male and female participants. The p-value was higher than 0.05 in relation to the four dimensions.

Table 9.

Differences Between Male and Female Teachers for Applying Emergency Remote Teaching During The COVID-19 in Accordance With Gender.

\begin{tabular}{llllllll}
\hline Dimension & Category & $\mathbf{N}$ & Mean & $\begin{array}{l}\text { Std. } \\
\text { Deviation }\end{array}$ & T-Test & DF & P-Value \\
\hline \multirow{2}{*}{ Preparation } & Male & 48 & 3.98 & 0.72 & -0.06 & 95 & 0.96 \\
& Female & 49 & 3.99 & 0.91 & & & \\
Implementation & Male & 48 & 3.78 & 0.82 & 0.08 & 95 & 0.94 \\
& Female & 49 & 3.77 & 0.79 & & & \\
Assessment & Male & 48 & 3.70 & 0.87 & -1.50 & 95 & 0.14 \\
& Female & 49 & 3.94 & 0.68 & & & \\
Barriers & Male & 48 & 1.34 & 0.60 & 1.38 & 95 & 0.17 \\
& Female & 49 & 1.18 & 0.55 & & & \\
\hline
\end{tabular}

\section{Student specialization differences}

The significant differences between the teachers' views about applying emergency remote teaching in accordance with their specialization were investigated through one Way ANOVA. The results showed no statistically significant differences among the participant students according to their specialization ( $\mathrm{p}$ value $>0.05)$.

Table 10.

Four Dimensions in Student Responses About Applying Emergency Remote Teaching During The COVID-19 in Accordance With Their Specialization.

\begin{tabular}{|c|c|c|c|c|c|c|}
\hline Dimension & Sources of variation & Sum of Squares & Df & Mean Square & $\mathbf{F}$ & $\begin{array}{l}\text { P-Value } \\
\text { (Sig.) }\end{array}$ \\
\hline \multirow{3}{*}{ Preparation } & Between Groups & 1.81 & 2 & 0.90 & 1.37 & 0.26 \\
\hline & Within Groups & 62.03 & 94 & 0.66 & & \\
\hline & Total & 63.83 & 96 & & & \\
\hline \multirow{3}{*}{ Implementation } & Between Groups & 0.65 & 2 & 0.33 & 0.50 & 0.61 \\
\hline & Within Groups & 60.94 & 94 & 0.65 & & \\
\hline & Total & 61.59 & 96 & & & \\
\hline \multirow{3}{*}{ Assessment } & Between Groups & 1.41 & 2 & 0.71 & 1.16 & 0.32 \\
\hline & Within Groups & 57.26 & 94 & 0.61 & & \\
\hline & Total & 58.67 & 96 & & & \\
\hline \multirow{3}{*}{ Barriers } & Between Groups & 0.11 & 2 & 0.06 & 0.17 & 0.85 \\
\hline & Within Groups & 31.57 & 94 & 0.34 & & \\
\hline & Total & 31.69 & 96 & & & \\
\hline
\end{tabular}




\section{Discussion}

The present study has focused on the real situation of applying emerging remote teaching during the COVID-19 pandemic by investigating the perspectives of postgraduate students at Prince Sattam bin Abdul-Aziz University. Majority of the participant students positively responded towards applying emergency remote teaching during the COVID-19, as it helped them in self-learning, expressing opinions, self-evaluating, advancement of technical expertise, and positive interaction in the learning environment. Similarly, Duke Kunshan University and New York University Shanghai offered examples of successful adaptation and rapid deployment of educational technology products (The Conversation, 2020). However, these universities did not face difficulty in implementation of remote learning as they had experience of using these technologies (Czerniewicz, 2020). The main hurdle, faced by universities of other countries like Prince Sattam bin Abdul-Aziz University is the availability of inadequate resources. The institutions have implemented online learning rapidly to establish familiarity with the important tools and teaching approaches. The present study has shown that majority of the participant students agreed on the use of technical programs that help teaching. However, the institutions need to avoid excessive demands and tensions associated with quick adoption of new strategies, as they lack preparation and planning measures. It is indicated that there is difference in emergency remote teaching and e-learning. Hodges et al. (2020), suggested that emergency remote teaching may be simply defined as procedure adopted by the teachers while introducing lessons to their students. In this study, the emergency remote teaching means the method of teaching by using a package of technologies, i.e. learning systems (Blackboard) or other applications (such as Zoom, YouTube, MS-Office) remotely at home whether synchronous (direct at the same time) or asynchronous (indirect), due to the COVID-19 pandemic. It is explained that researchers should not confuse e-learning with emergency remote teaching, and they should never discuss the usefulness of remote teaching.Therefore, Hodges et al. (2020) suggested that e-learning depends on careful educational planning and design that is held through a systematic model. The design process is carried out according to a systematic model that affect the quality of distance education. This model and planning are absent from emergency remote teaching currently. In the present study, respondents perceived that the course lecturer need to use variety of evaluation methods such as homework, presentations and participation in a discussion forum, and others, during emergency remote teaching. A similar study by Ali (2019) stated that some of the staff members tried to integrate information and communication technology during their lectures. However, majority of the course lecturers believed that there was a need to enhance confidence to use different tools and learning platforms. Another study by Gonzalez et al. (2020) focused on uncertain assessment process in higher education institutions during COVID-19 pandemic. The results depicted that distance learning changed the strategies of learning among students towards more continuous habit and improved their efficiency. A case study about Peking University highlighted five specific principles corresponding to online education (Bao, 2020). Those principles included; effective delivery based on online instructional information, improvement in students' learning through high-quality participation, increased correspondence between online instructional information and students' learning, and provision of adequate support to the students from faculty and teaching assistants. The conventional knowledge from the area of educational planning for formal education is not sufficient, considering the recent situation of COVID-19 pandemic (Karalis, 2020). Supporting the results of present study, Doghonadze et al. (2020) showed that distance learning can be done by all the teachers, even if they are not prepared for it. It is shown that majority of the teachers are trying their best to cope with the current situation and some of them have mastered too; however, there is much difference in the quality of education provided in remote learning. There are a lot of barriers experienced during online education; although, many technologies have evolved. These barriers include, installation issues, problems with video and audio, downloading errors, and login problems (Dhawan, 2020). This was in support of a previous study by Song et al. (2004) stating that major barriers faced by the students include technical problems and difficulty in understanding instructional goals during online learning. Another study by Parkes et al. (2014) stated that students exhibit low-level preparedness regarding the usage of Learning Management Systems. This clearly shows that established IT infrastructure is required in online learning; therefore, it needs to be strong and supported with unhindered services. The study findings have provided a snapshot of online learning in the context of students' perspectives. Therefore, this study is likely to play significant role in surveying other countries with inclusion of teachers as well. However, the study results were limited as the data was collected through single method approach. The study has only focused on the perspectives of students. While, it fails to compare the perspectives of teachers as well as students on the newly adapted teaching procedure. 


\section{Conclusion}

The stakeholders have been facing challenges amid the COVID-19 pandemic and social distancing measures, since they must perform in a resource-restrained and time constraint situation. The adoption of online learning environment needs to be considered as a pedagogical and instructional challenge, rather than just a technical issue. The present study has investigated the application of Emergency Remote Teaching during the COVID-19 crisis at Saudi Higher Education. The study concluded that majority of the students were positive about emergency remote teaching as it facilitated self-learning. The use of technology is involved in emergency remote teaching that requires cross-collaboration between instructional, content, and technological teams. Further, the study also showed that rapid mobilization across different resources and university staff is required as university closure and attending online lectures are the pedagogical transformation. The study also includes the viewpoint of the students regarding online learning and how the strong IT infrastructure can influence the online learning. Online learning has simplified the remote teaching process both for students and teachers with the help of various online tools and softwares. The study also determines the statistical difference between the teacher's perspectives in relation to the four dimensions that are preparation, implementation, assessment, and barriers. During Emergency Remote teaching the lecturer were tend to use different assessment procedures like presentations, online assignments, participation in a discussion forum, homework. The distant learning has improved the learning habit of students particularly at university.

\section{List of Abbreviations}

$\begin{array}{ll}\text { COVID-19 } & \text { New Coronavirus Disease } \\ \text { LMS } & \text { Learning Management Systems } \\ \text { PSAU } & \text { Prince Sattam bin Abdul-Aziz University }\end{array}$

\section{References}

Ali, W. (2019). The Efficacy of Evolving Technology in Conceptualizing Pedagogy and Practice in Higher Education. Higher Education Studies, 9(2), 81-95. https://doi.org/10.5539/hes.v9n2p81

Bao, W. (2020). COVID-19 and online teaching in higher education: A case study of Peking University. Human Behavior and Emerging Technologies, 2(2), 113-115. https://doi.org/10.1002/hbe2.191

Cho, R.H., Yeung, Z. W., Ho, O.Y., Lo, J.F., Siu, A.K., Kwan, W.M., ... \& Abdullah, V. (2020). Pearls of experience for safe and efficient hospital practices in otorhinolaryngology — head and neck surgery in Hong Kong during the 2019 novel coronavirus disease (COVID-19) pandemic. Journal of Otolaryngology-Head \& Neck Surgery, 49, 1-8. https://doi.org/10.1186/s40463-020-00427-4

Cronbach, L.J. (1951). Coefficient alpha and the internal structure of tests. psychometrika, 16(3), 297-334. https://doi.org/10.1007/bf02310555

Czerniewicz, L. (2020). What we learnt from "going online" during university shutdowns in South Africa. Phil on EdTech. Retrieved from https://philonedtech.com/what-we-learnt-from-going-onlineduring-university-shutdowns-in-south-africa/

Dhawan, S. (2020). Online Learning: A Panacea in the Time of COVID-19 Crisis. Journal of Educational Technology Systems, 49(1). 1-18. https://doi.org/10.1177/0047239520934018

Doghonadze, N., Aliyev, A., Halawachy, H., Knodel, L., Adedoyin, A.S., Al-Khaza'leh, B., \& Oladayo, T.R. (2020). The Degree of Readiness to Total Distance Learning in the Face of COVID-19-Teachers' View (Case of Azerbaijan, Georgia, Iraq, Nigeria, UK and Ukraine). Journal of Education in Black Sea Region 5(2), 2-41.

Field, A. (2017). Discovering statistics using IBM SPSS statistics $\left(4^{\text {th }}\right.$ ed). New York: SAGE.

Gonzalez, T., de la Rubia, M.A., Hincz, K.P., Comas-Lopez, M., Subirats, L., Fort, S., \& Sacha, G.M. (2020). Influence of COVID-19 confinement in students' performance in higher education. UAM. https://doi.org/10.35542/osf.io/9zuac

Hodges, C., Moore, S., Lockee, B., Trust, T., \& Bond, A. (2020). The Difference between Emergency Remote Teaching and Online Learning. Educause. Retrieved from: https://er.educause.edu/articles/2020/3/the-difference-between-emergency-remote-teaching-and-onlinelearning

IBM Corp. (2017). IBM SPSS Statistics for Windows. Version 25.0. Armonk, NY: IBM Corp.

Karalis, T. (2020). Planning and evaluation during educational disruption: lessons learned from COVID19 pandemic for treatment of emergencies in education. European Journal of Education Studies, 7(4), 125-142. https://doi.org/10.5281/zenodo.3789022 
Parkes, M., Stein, S., \& Reading, C. (2015). Student preparedness for university e-learning environments. The Internet and Higher Education, 25, 1-10. https://doi.org/10. 1016/j.iheduc.2014.10.002

Reimers, F. M., \& Schleicher, A. (2020). A framework to guide an education response to the COVID-19 $\begin{array}{lcc}\text { Pandemic of } & 2020 . & \text { OECsD. } \\ \text { https://www.hm.ee/sites/default/files/framework_guide_v1_002_harward.pdf. }\end{array}$

Reimers, F., Schleicher, A., Saavedra, J. \& Tuominen, S. (2020). Supporting the continuation of teaching and learning during the COVID-19 Pandemic: Annotated resources for online learning. OECD. Available: http://www.oecd.org/education/Supporting-the-continuation-of-teaching-and-learningduring-the-COVID-19-pandemic.pdf

Robson, C. (2002). Real world research: A resource for social scientists and practitioner-researchers (Vol.2). Oxford: Blackwell.

Sladdin, J. (2020). Coronavirus: risks in online delivery of education. Pinsentmasons. Available: https://www.pinsentmasons.com/out-law/analysis/coronavirus-education-online-delivery-risks

Song, L., Singleton, E. S., Hill, J. R., \& Koh, M. H. (2004). Improving online learning: Student perceptions of useful and challenging characteristics. The internet and higher education, 7(1), 59-70. https://doi.org/10.1016/j.iheduc.2003.11.003

The Conversation. (2020). Coronavirus pushes universities to switch to online classes — but are they ready? Retrieved from: https://theconversation.com/coronavirus-pushes-universities-to-switch-toonline-classes-but-are-they-ready-132728

World Bank. (2020a). Guidance Note on Remote Learning and COVID-19 (English). Washington, D.C. World Bank Group. Retrieved from: http://documents.worldbank.org/curated/en/531681585957264427/Guidance-Note-on-RemoteLearning-and-COVID-19

World Bank. (2020b). Rapid Response Briefing Note: Remote Learning and COVID-19 Outbreak (English). Washington, D.C.: World Bank Group. Retrieved from: http://documents.worldbank.org/curated/en/266811584657843186/Rapid-Response-Briefing-NoteRemote-Learning-and-COVID-19-Outbreak 